\title{
かん詰の内面腐食に関する研究 (VII)
}

\author{
アスパラガスかん詰のかん内面笍食と, シスチン, \\ システィンによるスズの溶出との関連性
}

(昭和 47 年 3 月 24 日受理)

\section{堀尾嘉 友* 吉田千恵子*}

Studies on the Internal Corrosion of Can (VII)

Internal Corrosion of Canned Asparagus and its Correlation to the Tin Dissolving Activity of Cystine, Cysteine and Asparagus

\author{
Takatomo HORIO and Chieko YOSHIDA
}

(Toyo Institute of Food Technology: 2-23-4 Minamihanayashiki, Kawanishi-shi, Hyogo-ken)

\begin{abstract}
It is well known that canned asparagus dissolves tin from uncoated inner surface of the can in the short term of storage after manufactured, however the cause of this phenomenon has not been known. The present paper deals with the internal corrosion of canned asparagus and its correlation to the tin dissolving activity of cystine, cysteine and asparagus.

Extract of asparagus freeze-dried and stored at room temperature for 0-3 years was subjected to the test packing in baby-food cans. Closed cans were sterilized at $120^{\circ} \mathrm{C}$ for 20 minutes and stored at $38^{\circ} \mathrm{C}$.

The corrosion factors were easily extracted with boiling methanol. They are inactive against cation exchange resin and stable in the acid medium but considerably unstable against alkaline solution. Thus, the action of detinning of four sulfur containing amino acids and relative substance were examined. When more than $500 \mathrm{ppm}$ of cystine is contained in the packed can, severe corrosion and sulfur stain was accelerated. Dried asparagus contained more than $15000 \mathrm{ppm}$ of cystine + cysteine.

The influence of oxygen or nitrogen substitution in the reaction medium were studied in the conection with the detinning action of cystine and cysteine. Cystine accelerated severe corrosion in the absence of oxygen, but cysteine promoted severe corrosion only at the presence of oxygen. Cystine and cysteine are assumed to be the factors which play one of the main roles in the proceeding of the corrosion in canned asparagus.
\end{abstract}

(Received March 24, 1972)

前報1で述べたようにかん詰食品は現在，その容器と して主にブリキかんが使用され, 内容物の種類により無 登装かん，または塗装かんが使いわけられている. 一般 的に無叙装かんを使用した場合，かん詰の製造時の脱気 処理操作の良否に基づく封入酸素量2) および食品の $\mathrm{pH}$ とその中に含まれる腐食因子の影響等により, 貯蔵中に かん材のスズが溶出するため, かん内が還元状態に保た れ内容物の色調, 香味の保持ならびにビタミンの減少が

* 東洋食品研究所: 兵庫県川西市南花屋教 4-23-2
阻止され食品価値の長期維持が可能となる反面, その容 出量の多い場合には食品衛生上問題となることが知られ ている8).

アスパラガスかん詰は製造後比較的短期間に著量のス ズおよび鉄を溶出することから，かん詰食品製造業界で は経験的に腐食性の強い食品に属寸るものの一つとして 分類されている4がなお拉てバラガスかん詰のスズの 溶出量に関しては Bigelow5), 森(1)，秋山7) らの報告が ある.ささに著者らはアスパラガス組織中に硝酸イオン 
の存在を認め報告した8) が，アスパラガスかん詰の $\mathrm{pH}$ が6.0 付近であることと, かん内面の黒変化がおこるこ と,および制造直後においても溶出スズ量が多いことか ら, 硝酸イオン以外の腐食因子の存在する可能性が考之 られ，しかもこの腐食因子はかん詰の製造工程9 から考 え, 加熱殺菌時に組織中より容易に溶出し, 耐熱性であ ると推定できる。このような観点からアスパラガスのス ズ溶出促進作用（以下腐食作用と略記する）について検 討を加えた結果，その組織中に多量に含まれるシスチン， およびシステインが特異的にスズの溶出を促進すること を認めたので報告する.

\section{実酫の部}

\section{1. 試料ならび測定方法}

\section{1-1. 試料の調製}

アスバラガスは当所農場で栽培したメリーワシントン $500 \mathrm{~W}$ 種で1967年 6 月, および1970年 5 月に収獲したホ ワイトおよびグリーンの嫩茎の鱗片葉を除去し, 洗浄後 凍結乾燥したのちかんに充てん, 真空巻締めして室温に 町蔵した．乾燥物の生鮮品に対する収量は6.8 8\%であ った。なお腐食作用の比較のために生鮮品む使用した。

\section{1-2. かんおよひ試験かん詰の製造}

HD ブリキを使用した内面無塗装のベビーフードかん を使用し、ヘッドスペースガスの影響をできるだけさけ る目的で試料溶液を満注し，巻締め機械の真空度（バキ ウムチャンバーゲージ) $55 \mathrm{~cm}$ で巻締め, $120^{\circ} 20$ 分間加 熱殺菌後ほぼ室温まで水冷し, 翌日開かん分析用の試験 かん詰を除き $38^{\circ}$ に貯蔵した。

\section{1-3. 溶出スス量の測定}

スズ含有量に応じ試験溶液 5 10g をとり前報1にしし たがって乾式灰化ののちポーラログラフ法により測定し た.

\section{1-4. シスチンおよびンステインの刡定}

シスチンを亜鉛アマルガム還元した後 2.6 ジクロルペ ンソキノンを発色試薬とする比色法 ${ }^{10)}$ とった。
2. 凍結乾燥アスパラカスス試料を用いた場合の腐食作 用と pH の影響

1-1 で述べたアスパラガスかん詰 (1967年 6 月製造)の グリーンおよびホワイトのほぼ同量をミキサーで混合, 粉末とし, その 1 部についてブレイ変法11)で硝酸性窒素 量を定量した結果 $0.5 \mathrm{ppm}$ であった。試料粉末 $145 \mathrm{~g}$ に 食塩 $0.5 \%$ ，ショ糖 $1.5 \%$ を含む液を加えて $4 \mathrm{~L}$ とし， ビーカーに入れ煮沸後ろ過鐘を用いて減圧下で脱気する 操作を 3 回繰返したのち 2 分し, $10 \%$ 塩酸または水酸化 ナトリゥム溶液を用いてそれぞれ $\mathrm{pH} 3.5$ ，または 6.0 としてかんに充てんし，1-2 により試験かん詰を製造し た。対照として，食塩 $0.5 \%$ ，およびショ糖 $1.5 \%$ を含む $0.2 \%$ クン酸水溶液を同一 $\mathrm{pH}$ としかんに充てん, 巻 締めた。経時的な溶出スズ量の变化を各群 3 かんについ ての測定平均值で Table 1 に示した。この測定成績か ら腐食作用は $\mathrm{pH}$ の低い場合に促進されることが判明し たが，実際のアスパラガスかん詰との対応性を考え，以 下の実験は $\mathrm{pH} 6.0$ 付近で, また腐食作用の比較は短期 間の貯蔵で可能なため， $38^{\circ}$ で 1 か月の貯蔵試験を行な らこととした。

\section{3. 腐食因子の水またはメタノールに対する挙動}

3-1. 熱水抽出

試料粉末 $50 \mathrm{~g}$ に水約 $1 \mathrm{~L}$ を加之10分間煮沸後吸引ろ 過し, 残留物は再び水約 $300 \mathrm{ml}$ を加え加熱後ろ過し, ろ液を合併し検液 I とした。残留物は水を加えて混和し 検液 II とした.

\section{3-2. 熱メタノール抽出}

試料粉末 $50 \mathrm{~g}$ にメタノール $2 \mathrm{~L}$ を加え還流冷却器を 付し, 水浴中で 8 時間加熱還流し冷後ろ過，万液を減王 留去後水に溶解し検液正とした. 残留物は蒸発ザラに移 し水浴上でメタノールを蒸発乾燥後，水を加えて10分間 煮沸後乃過，万液を検液IVとし，残留物に水を加えて検 液 $\mathrm{V}$ とした。

\section{3-3. 試験かん詰の彆造と貯蔵試験成績}

Table 1. Tin Dissolving of Canned Asparagus

$(\mathrm{ppm})$

\begin{tabular}{|c|c|c|c|c|c|}
\hline \multirow{2}{*}{ Samples } & \multirow{2}{*}{$\mathrm{pH}$} & \multicolumn{4}{|c|}{ Storage period } \\
\hline & & 0 & 2 weeks & 1 month & 3 months \\
\hline \multirow{2}{*}{ Asparagus } & 5.9 & 142 & 290 & 342 & 378 \\
\hline & 3.5 & 239 & 387 & 399 & 532 \\
\hline \multirow{2}{*}{ Control* } & 5.9 & 63 & 83 & 83 & 85 \\
\hline & 3.5 & 58 & 68 & 76 & 76 \\
\hline
\end{tabular}

Mean values of three cans.

Asparagus was freeze-dried and stored for three years. It was homogenized, boiled with water containing 0.5 percent $\mathrm{NaCl}$ and 1.5 percent sucrose, was packed in baby-food cans, and sterilized at $120^{\circ} \mathrm{C}$ for 20 minutes. Stored at $38^{\circ} \mathrm{C}$. * 0.2 percent citric acid solution containing $\mathrm{NaCl}$ and sucrose. 


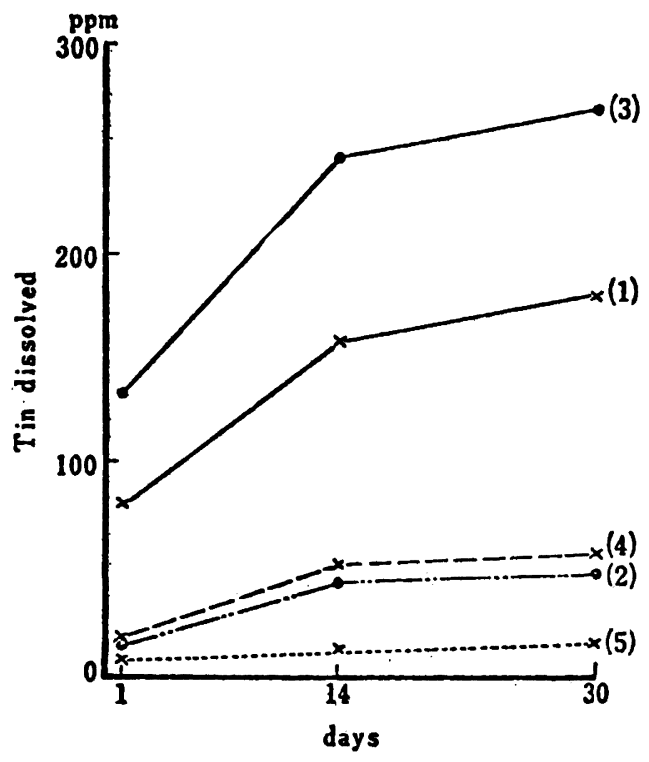

Fig. 1. Tin dissolving of canned asparagus extract

Freeze-dried and homogenized asparagus was treated as (1)-(5) and dissolved or mixed with water and packed in baby-food cans $\left(\mathrm{pH} \mathrm{6.0)}\right.$, and sterilized at $120^{\circ} \mathrm{C}$ for $20 \mathrm{mi}$ nutes. Stored at $38^{\circ} \mathrm{C}$.

(1) Boiling water extract.

(2) Residue of (1).

(3) Boiling methanol extract.

(4) Boiling water extract of residue of (3).

(5) Residue of (4).

Mean values of three cans were plotted.

検液 I 〜 Vにそれぞれ水を加えて $1.4 \mathrm{~L}$ とし， $\mathrm{pH}$ を 6.0 に調整後 1-2 によりかん詰を製造, 貯蔵試験を行な った. 経時的な溶出スズ量の変化を Fig. 1 に示したが, 腐食因子は熱水，とくに熱メタノールに容易に抽出され る. べつに生鮮アスパラガスについても同様に抽出, 試 験したが，抽出処理液では 2 週間後の溶出スズ量は 238 ppm で, 乾燥試料を用いた場合と同じ傾向であった。

\section{4. 俩食因子の 2，3 吸着剤に対する挙動}

この実験では試料粉末を 3-2 と同様にメタノールで抽 出後メタノールを留去した抽出エキスを試料粉末として 約 $25 \mathrm{~g}$ を水に溶解して用いた。

\section{4-1. 活性炭処理}

上記溶液に活性炭末 $12.5 \mathrm{~g}$ を加之10分間煮沸後ろ過, 残留物は再び水を加え煮沸後ろ過し，ろ液を合併し検液 Vとした，残留物はメタノールで熱時抽出し，メタノー ルを留去後水に溶解して検液VIとした。

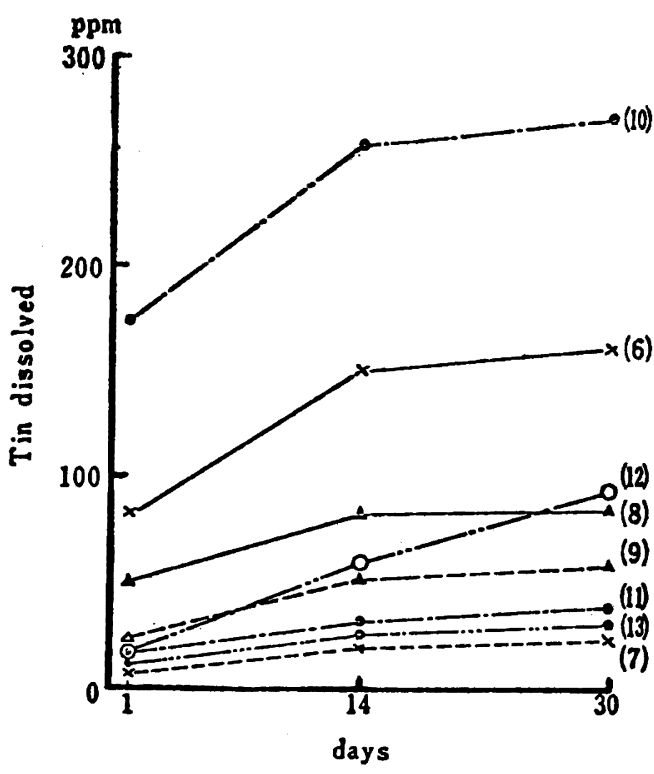

Fig. 2. Tin dissolving of canned asparagus extract

Extract of freeze-dried and homogenized asparagus with boiling methanol was dissol. ved in water and treated, packed in baby. food cans ( $\mathrm{pH} 6.0$ ) and sterilized at $120^{\circ} \mathrm{C}$ for 20 minutes. Stored at $38^{\circ} \mathrm{C}$.

(6) Treated with activated charcoal.

(7) Boiling methanol extract of residue (6).

(8) Effluent of activated alumina column.

(9) Acidic methanol extract of the above alumina.

(10) Effluent of cation exchange resin colunm.

(11) Treated with a half normal $\mathrm{HCl}$ of the above resine.

(12) Effluent of anion exchange resin column.

(13) Treated with normal $\mathrm{NaOH}$ of the above resin.

Mean values of three cans were plotted.

\section{4-2. アルミナ処理}

$200 \mathrm{~g}$ の活性アルミナを充てんしたカラムに前記溶液 を通過させ, 流出液を検液壮とした。 カラムは $0.1 \mathrm{~N}$ 塩 酸メタノール $5 \mathrm{~L}$ で溶出し, メタノールを留去後水に溶 解, 中和して検液IXとした。

\section{4-3. イオン交換樹脂処理}

$35 \mathrm{~g}$ のアンパーライト200を充てんしたカラムを H型

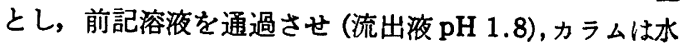
で洗浄し, 流出液は合併し検液 Xとした。樹脂は $0.5 \mathrm{~N}$ 塩酸で溶出し検液XI とした。 またべつに $35 \mathrm{~g}$ のアンパ ーライト IR-410を充てんしたカラムを $\mathrm{OH}$ 型とし, 前 
記溶液を通過させ（流出液 $\mathrm{pH}$ 10.2），カラムは水で洗 浄, 流下液は合併し検液XII とし。樹脂は $1 \mathrm{~N}$ 水酸化ナ トリウム溶液で溶出し検液Xとした。この溶出には長時 間を要した。

\section{4-4. 試験かん詰の赀造と貯花試験成繶}

検液V-X直をそれぞれ pH 6.0 に調整し水を加えて 700 $\mathrm{ml}$ とし，1-2 によりかん詰とし貯蔵試験を行ない，経 時的な溶出スズ量の変化を Fig. 2 に示した。腐食因子 は活性炭, アルミナ等には吸着され難い。また陽イオン 交換樹脂にはほとんど吸着されず，陰イオン交換樹脂に 吸着された。一方この樹脂のアルカリ溶出液では腐食作 用がほとんど認められないことから，溶出操作時に長時 間フルカリ性としたため腐食因子が分解したものと考え られた。

\section{5. 腐食因子の酸またはアルカリに対する安定性}

夷験 4 と同量の抽出エキス水溶液を水で $150 \mathrm{ml}$ とし, 水酸化ナトリゥム $6 \mathrm{~g}$ を加え溶解した。 またべつに塩酸 $17 \mathrm{ml}$ を加え混和した。これら両者を室温に18時間保持 したのち，それぞれ $\mathrm{pH} 6.0$ に調整し水を加えて $700 \mathrm{ml}$ とした後かんに充てんし1-2によりかん詰とした，各貯 蔵区の溶出スズ量を Table 2 に示したが，腐食作用は アルカリ性とすることにより減少した.

\section{6. 含硫アミノ酸等の腐食作用の検討}

モデル溶液として大塚らの報告12)に基づき，フスパラ ガス中に含まれる有機酸のうち比較的含量の多いクェン 酸, リンゴ酸, およびピログルタミン酸を選び，それぞ れ $0.81 \mathrm{~g} ， 0.74 \mathrm{~g}$ および $0.31 \mathrm{~g}$ を合わせて水に溶解し て $1 \mathrm{~L}$ とし $\mathrm{pH} 6.0$ に調整した液を使用し, それぞれメ チルメチオニンスルホニウムクロライド18), メチオニン, シスチン，またはシステインの $1000 \mathrm{ppm}$ で溶液をつく ク，pHを6.0に調整しかんに充てん，巻締めた. シス チンは液性を变えて溶解したが， $\mathrm{pH}$ をもどすと結晶が
Table 2. Stability of Detinning Substance in Asparagus

(ppm)

\begin{tabular}{l|c|c|c}
\multirow{2}{*}{$\begin{array}{c}\text { Treatment } \\
\text { with }\end{array}$} & \multicolumn{3}{|c}{ Storage period } \\
\cline { 2 - 4 } & 0 & 2 weeks & 1 month \\
\hline Alkaline & 90 & 122 & 144 \\
Acid & 145 & 196 & 251 \\
Untreated & 160 & 200 & 228
\end{tabular}

Mean values of three cans.

Methanol extract dissolved in $\mathrm{N}-\mathrm{NaOH}$ or $\mathrm{N}-\mathrm{HCl}$ and allowed to stand for 18 hours at room temperature, then $\mathrm{pH}$ was adjusted to 6.0 and packed in baby-food cans and sterilized at $120^{\circ} \mathrm{C}$ for 20 minutes.

析出するため, 結晶浮遊液を十分混合してかんに入れた. 各貯蔵区の溶出スズ量の変化を Table 3 に示したが, シスチン添加時にのみ著しいスズの溶出を認め，あわせ てかん内面の黒変化がみられた。

\section{7. シスチンとシステインとの度食作用の比較}

実験 6 ではシスチン浮遊液を使用したためかん詰製造 時にシスチンが流出し封入量を正確に一定とすることが 困難であった．各かん相互の封入量を一定とし，またシ スチン濃度と腐食作用の関係を調べるため, シスチンの 8.3，41.5，83 および $830 \mathrm{mg}$ をそれぞれ秤量して第 7 改正日本薬局方に規定されたカプセルに封入してかんに 入れ，前記モデル溶液を加えて1-2によりかん詰を製造 した。 かん詰内のシスチン濃度はそれぞれ $100 ， 500$, 1000 および 10000 ppm である. 対照として空カプセル にモデル溶液を加えたかん詰を製造した。 システイン溶 液の濃度を变えた場合についても検討し，これらかん詰

Table 3. Tin Dissolving Activity by Sulfur Containing Compounds

\begin{tabular}{|c|c|c|c|c|c|c|}
\hline \multirow{3}{*}{ Sulfur compounds } & \multicolumn{6}{|c|}{ Storage period } \\
\hline & \multicolumn{2}{|c|}{0} & \multicolumn{2}{|c|}{2 weeks } & \multicolumn{2}{|c|}{3 weeks } \\
\hline & Sulfur stain & $\mathrm{Sn}(\mathrm{ppm})$ & Sulfur stain & $\mathrm{Sn}(\mathrm{ppm})$ & Sulfur stain & $\mathrm{Sn}(\mathrm{ppm})$ \\
\hline $\begin{array}{l}\text { Methyl methionine sulfonium } \\
\text { chloride }\end{array}$ & - & 76 & - & 101 & - & 101 \\
\hline Methionine & - & 70 & - & 74 & - & 87 \\
\hline Cystine & 世 & 339 & 世 & 378 & 世 & 378 \\
\hline Cysteine & $H$ & 86 & $H$ & 98 & $H$ & 115 \\
\hline $\begin{array}{l}\text { Mixture of the above } 4 \mathrm{com} \text { - } \\
\text { pounds }\end{array}$ & H & 340 & W & 363 & 世 & 385 \\
\hline Control & - & 69 & - & 67 & - & 75 \\
\hline
\end{tabular}

Each compounds were dissolved in model solution containing citric acid ( $810 \mathrm{ppm})$, malic acid $(740 \mathrm{ppm})$, and pyroglutamic acid $(310 \mathrm{ppm})$. The final concentration was $1000 \mathrm{ppm}$ and $\mathrm{pH} 6.0$. The solutions were packed in baby-food cans and sterilized at $120^{\circ} \mathrm{C}$ for 20 minutes and stored at $38^{\circ} \mathrm{C}$.

Mean values of three cans 
Table 4. Comparison of Detinning Actions of Cystine and Cysteine

\begin{tabular}{|c|c|c|c|c|c|c|c|c|}
\hline \multirow{3}{*}{ Sample } & \multirow{3}{*}{ Capsule } & \multirow{3}{*}{$\begin{array}{l}\text { Concent- } \\
\text { ration } \\
(\mathrm{ppm})\end{array}$} & \multicolumn{6}{|c|}{ Storage period } \\
\hline & & & \multicolumn{2}{|l|}{0} & \multicolumn{2}{|c|}{2 weeks } & \multicolumn{2}{|c|}{1 month } \\
\hline & & & Sulfur stain & $\mathrm{Sn}(\mathrm{ppm})$ & Sulfur stain & Sn (ppm) & Sulfur stain & $\mathrm{Sn}(\mathrm{ppm})$ \\
\hline \multirow{4}{*}{ Cystine } & 1 & 100 & \pm & 103 & \pm & 113 & \pm & 104 \\
\hline & 1 & 500 & + & 137 & H & 255 & H & 314 \\
\hline & 1 & 1000 & W & 252 & 冊 & 431 & 冊 & 463 \\
\hline & 3 & 10000 & m & 443 & 曲 & 1225 & 曲 & 1280 \\
\hline \multirow{2}{*}{ Control } & 1 & 0 & - & 71 & - & 86 & - & 86 \\
\hline & 3 & 0 & - & 90 & - & 111 & - & 114 \\
\hline \multirow{3}{*}{ Cysteine } & 0 & 100 & \pm & 82 & \pm & 87 & \pm & 81 \\
\hline & 0 & 1000 & $H$ & 90 & $H$ & 103 & H & 103 \\
\hline & 0 & 10000 & H & 63 & $H$ & 67 & $H$ & 79 \\
\hline Control & 0 & 0 & - & 83 & - & 72 & - & 71 \\
\hline
\end{tabular}

Cystine crystals were stuffed in gelatin capsules (Japanese Phamacopoeia VII)and packed in babyfood cans with model solution (see foot note in Table 3), pH 6.0. Cysteine was dissolved in the model solution, packed, sterilized at $120^{\circ} \mathrm{C}$ for 20 minutes and stored at $38^{\circ} \mathrm{C}$.

Mean values of three cans

の溶出スズ量の変化を Table 4 に示した.

8. アスパラガス中のシスチン, システイン量

1-4 の方法でシステインとして算出した。 2 年貯蔵の かん詰アスパラガス中 $695 \mathrm{ppm}$ ，凍結乾燥試料は 13,800 $\sim 15,000 \mathrm{ppm}$, メタノール抽出エキス $10,500 \mathrm{ppm}$, 同 残留物 $1,875 \sim 2,290 \mathrm{ppm}$ が検出された。

7. シスチンまたはシステインによるススの溶出にお よほすす酸素または空素置換の影響
スズ板 前報14)記載の $99.99 \%$ の $0.2 \mathrm{~mm} \times 5 \mathrm{~cm} \times 10$ $\mathrm{cm}$ のスズ板を秤量して使用した.

ガス導入管および還流冷却器を付けた 2 この 2 頸フラ スコに実験 6 に示したモデル溶液 $200 \mathrm{ml}$ を入れ，酸素 を10分間導入置換後スズ板を入れ，さらに一方にシスチ ン $1 \mathrm{~g}$ を加觉それぞれ酸素を導入しながらアスベスト上 で直火で加熱した。1 時間毎に火を去り室温まで急冷し 反応液の $1 \mathrm{ml}$ (シスチン無添加）または $0.5 \mathrm{ml}$ (シス

Table 5. Influence of Nitrogen or Oxygen Substitution in Flask upon Detinning Actions of Cystine or Cysteine

\begin{tabular}{|c|c|c|c|c|c|c|c|}
\hline \multirow{2}{*}{ Samples } & \multirow{2}{*}{$\begin{array}{l}\text { Substituted } \\
\text { with }\end{array}$} & \multirow{2}{*}{$\begin{array}{l}\text { After } 1 \text { hour } \\
\text { Sn ppm* }\end{array}$} & \multirow{2}{*}{$\begin{array}{l}\text { After } 2 \text { hours } \\
\text { Sn ppm* }\end{array}$} & \multicolumn{4}{|c|}{ After 3 hours } \\
\hline & & & & $\mathrm{pH}$ & Sn ppm* & Sn ppm** & Sulfur stain \\
\hline \multirow{2}{*}{ Cystine } & $\mathrm{N}_{2}$ & 1580 & 2040 & 6.0 & 2120 & 1980 & $H$ \\
\hline & $\mathrm{O}_{2}$ & 2580 & 3120 & 5.6 & 3120 & 4406 & HI \\
\hline \multirow[t]{2}{*}{ Cysteine } & $\mathrm{N}_{2}$ & 38 & 50 & 6.0 & 60 & 60 & \pm \\
\hline & $\mathrm{O}_{2}$ & 1220 & 2760 & 5.6 & 2460 & 3293 & HI \\
\hline \multirow[t]{2}{*}{ Control } & $\mathrm{N}_{2}$ & 5.6 & 6.3 & 6.0 & 6.5 & 47 & - \\
\hline & $\mathrm{O}_{2}$ & 430 & 430 & 6.7 & - & 626 & - \\
\hline
\end{tabular}

Either nitrogen or oxygen gas was bubbled for 10 minutes into $200 \mathrm{ml}$ of the model solution (see foot note in Table 3), then pure tin plate $(5 \mathrm{~cm} \times 10 \mathrm{~cm} \times 0.2 \mathrm{~mm})$ and one gram of cystine or cysteine had been added. The mixture was boiled for 3 hours under bubble of either gas. As the control samples, cystine or cysteine was removed from the reaction media.

* Analyzed by polarography.

** Calculated from the decrease of weight of the tin plate. 
チン添加）をとり，塩化フンモニウムおよび塩酸よりな る支持電解液を加えて $10 \mathrm{ml}$ とし，ポーラログラフ法で 溶出スズ量を測定した． 3 時間加熱反応後スズ板をとり 出し, 水洗䫧燥後科量し見かけのスズ溶出量をも算出し た．酸素の代りに窒素を用いた場合，あるいはシスチン の代りに当量のシステイン塩酸塩を同一 $\mathrm{pH}$ で反応させ た場合についても検討し，その成績を Table 5 に示し たまた各反応液についてロ紙クロマトグラフィーを行 なった（東洋滤紙 No. 50, 室温上昇法, 15時間展開, 検出試薬ニンヒドリン) シスチンとスズとの反応液では 酸素，または窒素置換のいずれの場合もシステインおよ びアラニンを検出した．また反応液について紫外部吸収 スペクトルを測定したが，波長 $190 \mathrm{~m} \mu$ に唯一の四収極 大を認めた，この吸収極大は標準としたシスチン，シス テインおよびフラニンのいずれにも認められるものであ った.

\section{考察}

はじめに述べたようにアスパラガスかん詰は $\mathrm{pH}$ が 6.0 付近であるにもかかわらず，製造後短期間でかなり のスズを溶出し，しかもかん内面が黒变する特徵があ る.この黒変化とスズの溶出が同一物質に基因するかど らかはべつとして, まずスズの溶出促進物質の解明を試 みた，生鲜物の長期保存が困難なためと熱変化を避ける 目的で涷結乾燥後かん詰として貯蔵した。スズ溶出促進 作用の検討は内容積の小さなベビーフードかんを用い室 温での満注法により充てん条件を一定としてかん詰を作 り加熱殺菌後経時的に分析した。へッ゙スペース，真空 度, 内容量, $\mathrm{pH}$ 等は毎回の分析時に測定したが，全試 験を通じて大差がないためと, 実験結果の判断に著しい 影䈏をおよぼさないと考えられるため必要以外は記述を 省略した。

まず長期貯蔵試料の腐食作用は生鮮品と大差が認めら れず，かん詰の製造殺菌直後に批いてもかん内面の黒変 化がみられ，また 1 月間貯蔵後の溶出スズ量は $340 \mathrm{ppm}$ に達し, 腐食因子の耐熱性が明らかである。この物質は 熱メタノール，熱水に容易に抽出されるが，処理の容 易さと腐食性の点より熱メタノール抽出ェキスとして検 討した，腐食因子は活性炭，アルミナ等には吸着され難 く，また溶出液も腐食性が少ない，陽イオン交換樹脂に は非吸着性であった，陰イオン交換樹脂処理では流下液 および溶出液にも腐食性が認められなかったことから， アルカリ性での分解が考えられた. そのため抽出エキス 溶液の酸性またはアルカリ性での安定性を検討したとこ ろ，酸性域では安定であるのに反し， $1 \mathrm{~N}$ 水酸化ナトリ ウム溶液とした場合腐食性の減少とともに黒変化作用の 低下が判明した。この事実より腐食性就よび黒変化が同 一物質に基づくものと考え，その対象として，アスパラ ガス中に含まれる主な含硫アミノ酸 4 種を選び， 1,000 $\mathrm{ppm}$ の添加濃度での モデルかん詰等の腐食性ならびに
黒変化を検討した、メチルメチオニンスルホニウム塩, 拉よびメチオニンではスズの溶出, かん内面の黑变化の 両作用とも認められなかった。 システインでは黒変化は おこる15)が，スズの溶出促進作用は僅少であった。しか しシスチンは両作用がきわめて顕著であった，濃度によ る影響も考えられるため, シスチンまたはシステインの 添加量をかえ, 比較検討を行ならと, シスチン添加時に はかん詰の製造殺菌処理直後においてそのほとんどが溶 解し, $500 \mathrm{ppm}$ 以上の添加で著しいスズの溶出と黒変化 がみられ，急激に反応したことが判明した。シスチン， システイン両者の可逆的な性質と, 試験かん詰内の封入 酸素との組合わさった影響が考えられるため，ガラス器 内モデル実験により，酸素または空素置換した場合のシ スチン, あるいはシステインの腐食作用について検討し た。シスチンによるスズの溶解は酸素の存在なしでおこ るのに反し，システインでは酸素の存在下ではじめてス ズが溶解する．またシスチンによるスズの黒変化は酸素 の存在下ではとくに顕著であることから，シスチンの -S-S-結合の開裂がスズの溶出を支配する酸化的溶出反 応と考えられる。一方システインによるスズの溶出，お よび黒変化は酸素の存在なしにはおこらないことと，反 応成績物の一つとしてアラニンを検出したことから酸化 的脱硫反応にともなうスズの溶出と考えられる．他方了 スパラガス中のシスチンおよびシステイン量を本報記載 の方法 ${ }^{10}$ 扎よび倉富らの方法16)の 2 方法で測定した。両 者の測定值に差があるため現在さらに検討中であるが今 回述べた方法によると長期貯蔵の市販かん詰中に少なく 凍結乾燥試料中には多量が検出された。これらはいずれ も試料の加熱抽出処理後測定したため, この処理でシス チン，あるいはシステインとして遊離したことも考えら れるのでこの点についても合わせて検討中である. 上述 のようにシスチンとシステインとではスズに対する作用 の明らかな相違があり, 試料アスパラガス中に両者が検 出されたが，市販フスパラガスかん詰の製造条件からか ん内酸素を皆無にすることができないことと，一方 $\mathrm{pH}$ が中性付近であるため, ジュース，果実等の低 $\mathrm{pH}$ のか ん詰でみられるような急激な酸素の減少がおこらないこ とを合わせ考えると，フスパラガス中のシステインの一 部が加熱殺菌処理時の初期にシステインに酸化されるこ とも考えられる.これらのことからアスパラガスかん詰 のスズの溶出ならびに黒変化の原因の一つとしてシスチ ンおよびシステインが大きな役割りを演じていると考え られる。

\section{総 括}

アスパラガスのスズ溶出促進物質を調べるため凍結乾 燥処理を行ない検討した。

スズの溶出作用と黒変化とは並行する.

凍結乾燥, 加熱, 酸性域で安定, アルカリ性で不安定 である。 
以上の知見から含硫アミノ酸および関連化合物の腐食 作用について検討した。メチルメチオニンスルホニウム 塩, およびメチオニンはスズ溶出作用も黒変化作用も認 められない。

シスチンは酸素の存在なしに激しくスズを容出する が，黒変化は酸素存在下で著しい。

システインは酸素の共存下で初めてスズを溶出し, 同 時に黒変化をおこす。

アスパラガスかん詰にみられるスズの多量溶出の原因 の 1 つは組織中に含まれるシスチンおよびシステインに 基因するものと考えられる.

\section{謝辞}

本研究に当り, 試料アスパラガスを提供して頂いた当 所黛研究室宮崎正則氏ならびに凍結乾燥処理の労をとら れた下田吉夫氏に感謝の意を表します。

文献

1）堀尾募友, 岩本喜伴, 小村祥子：食衛誌。11, 147 (1970).

2）岩本喜伴：未発表。

3）厚生省食品衛生課：食品衛生研究 16 (9)，871 (1966).

4）缶詰製造講議 1， p. 385 (1970) 日本缶詰協会.

(5 Bigelow, W. D.: J. Ind. Eng. Chem. 8, 813
(1916).

6) 森 光国, 鈴木 健, 河原伸江：缶詰事報。 48 (9), 67 (1969).

7）秋山尚子，大浦淑子：日本食品衛生学会第 21 回 学術講演会報告 (昭和 46 年 5 月).

8）岩本喜伴, 宮崎正則, 国里進三, 前田琇子, 珮尾 嘉友：栄美と食粠 21，47 (1968).

9）缶詰製造講議 II, p. 436 (1970) 日本缶詰協会.

10）赤堀四郎，金子武夫，成田耕造：蛋白倎化学 I, 332 (1969) 共立出版.

11) Woolley, J. T., Hicks, G. P., Hageman, R. H.; J. Agr. Food Chem. 8 (6), 481 (1960).

12）大塚 滋, 岩本喜伴, 下田吉夫, 毛利威徳, 青山 延子：東洋食品工業短大, 東洋食品研究所報告 6, 97 (1964).

13) Challenger, F., Hayward, B. J.: Chem. Ind. 19, 729 (1954).

14）堀尾嘉友，岩本喜伴，小村祥子：食衛誌. 9, 133 (1968).

15) Pigott, G. M., Dollar, A. M.: Food Tech. 17 (4), 115 (1963).

16) Kuratomi, K., Ohno, K., Akabori, S.: J. Biochem. 44 (3), 183 (1957). 